\title{
A cidade em nós: discursos, objetivações e subjetivações
}

\section{The city in us: discourses, objectivations and subjetivities}

\author{
Vanice Maria Oliveira SARGENTINI \\ Universidade Federal de São Carlos (UFSCar) \\ Kátia Menezes de SOUSA \\ Universidade Federal de Goiás (UFG) \\ Antônio FERNANDES JUNIOR \\ Universidade Federal de Goiás (UFG)
}

\begin{abstract}
RESUMO: Movidos por relações entre os dispositivos de segurança, que configuram as sociedades de biopoder, e os corpos dos indivíduos organizados conforme as funções que devem ser asseguradas pelo espaço, é que propomos pensar a população na materialidade discursiva da cidade que, tanto surge como resultado dos saberes que objetivam a multiplicidade de indivíduos, quanto funciona como técnica de subjetivação na construção do sujeito população na atualidade. As análises flagram textos e imagens dispersos nas cidades, focalizando as funções de higiene corporal, circulação de mercadorias e segurança do corpo. Os resultados indicam a presença de processos de objetivação que convivem com formas de resistências, que afetam tanto a sensibilidade corporal dos cidadãos quanto o corpo da população.
\end{abstract}

PALAVRAS-CHAVE: Cidade. Subjetivação. Percepção do corpo. Discurso.

ABSTRACT: We propose to think the population in discursive materiality of the city, that both arises as a result of knowledge aimed at the multitude of individuals as acts as subjectivity technique in the construction of the subject population today, guided by relations between the security devices which shape societies of biopower, and the bodies of organized individuals as the functions to be provided by space. The analyses catch texts and images freely in cities, focusing on the functions of personal hygiene, movement of goods and safety of the body. The results indicate the presence of objectification processes that live together with forms of resistance, which affect both the body sensitivity of the citizens as the body of the population.

KEYWORDS: City. Subjectivity. Body perception. Discourse.

\section{Introdução}

Em aula de 11 de janeiro de 1978, primeira de um conjunto de aulas publicadas em Segurança, território e população, Michel Foucault (2008, p. 03) a inicia informando que gostaria de começar o estudo com algo que ele havia chamado de biopoder: "o conjunto dos mecanismos pelos quais aquilo que, na espécie humana, constitui suas características biológicas fundamentais vai poder entrar numa política, numa estratégia política, numa estratégia geral de poder". Em aula seguinte, Foucault (2008) compara o dispositivo de segurança, mecanismo do biopoder que vai se instaurando a partir do século XVIII, com o dispositivo disciplinar que o antecede, mas também o acompanha. Enquanto a disciplina funciona de forma que, na medida em que isola um espaço, também determina um segmento, concentrando, centrando e encerrando, os dispositivos de segurança, ao contrário, tendem a ampliar e novos elementos são o tempo todo integrados: "a produção, a psicologia, os comportamentos, as maneiras de fazer dos produtores, dos compradores, dos consumidores, dos 
importadores, dos exportadores, integra-se o mercado mundial" (FOUCAULT, 2008, p.59). O espaço configurado pelas já conhecidas estruturas da lei e da disciplina e que vai se capitalizando pelos estratégicos mecanismos de segurança deve garantir multiplicidades organizadas para assegurar quatro funções, conforme Foucault (2008): a higiene, o comércio interior da cidade, a circulação de mercadorias externas e a vigilância.

Assim, a segurança vai se apoiar em certo número de dados materiais, procurando criar um ambiente em função de acontecimentos e elementos possíveis que precisam ser regularizados num contexto multivalente e transformável, um espaço que, conforme Foucault, chamamos de 'meio'. Em seu esclarecimento, trata-se daquilo "que é necessário para explicar a ação à distância de um corpo sobre outro. É, portanto, o suporte e o elemento de circulação de uma ação" (FOUCAULT, 2008, p. 27). O meio é um campo de intervenção em que, em vez de atingir os indivíduos como uma multiplicidade de organismos, de corpos capazes de desempenhos requeridos como na disciplina, vai atingir a população, "uma multiplicidade de indivíduos que são e que existem profunda, essencial, biologicamente ligados à materialidade dentro da qual existem" (FOUCAULT, 2008, p. 28).

Movidos por essas relações entre os dispositivos de segurança, que configuram as sociedades de biopoder, e os corpos dos indivíduos organizados conforme as funções que devem ser asseguradas pelo espaço, é que propomos pensar a população na materialidade discursiva da cidade que, tanto surge como resultado dos saberes que objetivam a multiplicidade de indivíduos, quanto funciona, pelas relações de poder que engendra, como técnica de subjetivação na construção do sujeito população na atualidade.

\section{Foucault inaugura o corpo nos estudos do discurso: o corpo e a cidade}

Foucault (1987), considerando que os historiadores já vinham abordando a história do corpo há bastante tempo e os campos em que fora estudado, propõe a ideia de que o corpo esteja também imerso num campo político, visto que as relações de poder têm alcance imediato sobre ele. Elas o marcam, o investem, o dirigem, o sujeitam a trabalhos, a obrigações cerimoniais, cobram-lhe sinais. Tal "investimento político do corpo está ligado, segundo relações complexas e recíprocas, à sua utilização econômica" (FOUCAULT, 1987, p. 25). Por corpo político entende o conjunto dos elementos materiais e das técnicas que servem de armas, de reforço, de vias de comunicação e de pontos de apoio para as relações de poder e de saber que investem o corpo e o submetem, fazendo dele objeto de saber. É nesse sentido que, conforme Martins (2006), a proliferação crescente de saberes e tecnologias políticas sobre os corpos implicados tanto como indivíduos quanto como integrantes de uma população constitui uma perspectiva histórica original na obra de Foucault. Segundo o autor, e nós concordamos com ele, as disciplinas do corpo e a regulação das populações, ao estabelecerem o grande contraponto analítico às liberdades formais e jurídicas modernas, constituirão o fio condutor sobre o qual Foucault construirá uma singular crítica da modernidade. Os saberes biomédicos e a medicina, colocados sob o foco da arqueologia e da genealogia das técnicas de governo, revelarão seu papel biopolítico na constituição de nossa herança moderna.

Demonstrando os modos como as tecnologias de poder deixam de visar aos indivíduos como indivíduos e passa a visar à população, Foucault (2012a, p. 179) comenta que "o século XVIII descobriu esta coisa capital: o poder não se exerce simplesmente sobre os sujeitos, [...]. Descobre-se que aquilo sobre o qual o poder se 
exerce é a população". Explicando o que significa dizer população, considera que se trata de grupo de seres vivos atravessados, comandados, regidos por processos, leis biológicas, que tem uma taxa de natalidade e mortalidade, uma curva e uma pirâmide de idade, uma morbidez, um estado de saúde, e mais, que uma população pode perecer, mas também se desenvolver. Para ele, a descoberta da população é a descoberta do indivíduo e do corpo adestrável e, ao mesmo tempo, o outro núcleo de tecnologia em torno do qual os procedimentos políticos do Ocidente se transformaram. A biopolítica foi, assim, inventada.

A sua invenção se dá concomitantemente ao aparecimento de problemas ligados ao do habitat, das condições de vida em uma cidade, a higiene pública, a modificação da relação entre natalidade e mortalidade. Ocorrem duas grandes revoluções na tecnologia do poder: a descoberta da disciplina e a descoberta da regulação da população com o aperfeiçoamento de uma biopolítica. Foucault (2012a, p. 180) continua sua explanação, mostrando que, a partir do século XVIII, "a vida se tornou agora um objeto de poder. A vida e o corpo. Outrora, havia apenas sujeitos, sujeitos jurídicos dos quais se podiam retirar os bens, aliás, a vida também. Agora, há corpos e populações". Instaura-se, assim, um tipo de sociedade em que o poder da lei está em vias de integrar-se a um poder muito mais geral, o da norma, e, conforme Foucault (2011, p. 395), isso implica um sistema de vigilância e controle diferente:

\begin{abstract}
uma visibilidade incessante, uma classificação permanente dos indivíduos, uma hierarquização, uma qualificação, o estabelecimento de limites e de diagnósticos. A norma se torna o critério de divisão dos indivíduos. Dado o fato de estar sendo constituída uma sociedade da norma, a medicina, como a ciência acima de tudo do normal e do patológico, será a ciência rainha.
\end{abstract}

O corpo torna-se uma realidade biopolítica e a medicina, uma estratégia biopolítica, nos termos de Foucault (2003), ao expor sua hipótese de que o capitalismo, desenvolvendo-se em fins do século XVIII e início do século XIX, socializou um primeiro objeto que foi o corpo enquanto força de produção e de trabalho. Nesse sentido, o controle da sociedade sobre os indivíduos começa no corpo e com o corpo, pois "foi no biológico, no somático, no corporal que, antes de tudo, investiu a sociedade capitalista" (FOUCAULT, 2003, p. 80). Esse controle se apresenta infiltrado de técnicas de saber e de poder; um poder que se coloca ao lado da vida da população, o biopoder. É assim que as tecnologias políticas passam a "investir sobre o corpo, a saúde, as maneiras de se alimentar e de morar, as condições de vida, todo o espaço da existência" (FOUCAULT, 1988, p. 135). Por se tratar de um poder centrado na vida, faz-se a distribuição dos indivíduos em torno da norma, o que resulta numa sociedade normalizadora que reivindica o direito à vida, ao corpo, à saúde, à felicidade, à satisfação das necessidades.

Outro fenômeno participa como suporte para a configuração da sociedade normalizada e normalizadora: a urbanização. Foucault (2003) descreve como, nessa mesma época, sentiu-se necessidade de constituir a cidade como unidade, de organizar o corpo urbano de modo coerente, homogêneo e bem regulamentado. Foucault (2003) apresenta várias razões para a unificação do poder urbano e, entre as razões econômicas e políticas, desenhadas pelo fato de a cidade ser um lugar de mercado e de produção, o que vai exigir mecanismos de regulação homogêneos e coerentes, e ser habitada por diferentes grupos de indivíduos e invadida por grupos pobres que vinham do campo, o que vai produzir a necessidade de um poder político capaz de esquadrinhar a população urbana, estão aí as razões ligadas ao medo urbano. 
Nasce o que eu chamarei medo urbano, medo da cidade, angústia diante da cidade que vai se caracterizar por vários elementos: medo das oficinas e fábricas que estão se construindo, do amontoado da população, das casas altas demais, da população numerosa demais; medo, também, das epidemias urbanas, dos cemitérios [...] (FOUCAULT, 2003, p. 87).

Para dominar esses medos que inquietam a população das cidades, intervêm mecanismos para por em prática planos de urgência, tais como: controle da circulação, sistema de vigilância, esquadrinhamento das cidades em bairros, revista dos habitantes, desinfecção, medicalização da cidade. Tais planos de urgência surgem diante dos problemas advindos com a urbanização, como forma de responder à indagação "sobre o que deve ser da ordem de uma sociedade, o que deve ser uma cidade, tendo em vista as exigências de manutenção da ordem, tendo em vista também que é preciso evitar as epidemias, as revoltas, promover uma vida familiar conveniente e conforme à moral" (FOUCAULT, 2012b, p. 206). Dessa possibilidade de manter a ordem, ou dessa vontade de ordem urbana, surge, também, a contínua busca pelo bem-estar, pelo domínio do corpo, adquirido pelo efeito do investimento do corpo pelo poder: "a ginástica, os exercícios, o desenvolvimento muscular, a nudez, a exaltação do belo corpo ... tudo isso está na linha que conduz ao desejo de seu próprio corpo por um trabalho insistente, obstinado, meticuloso que o poder exerceu [...] sobre o corpo em boa saúde" (FOUCAULT, 2014, p. 259).

O bem-estar dos indivíduos, assunto que será tratado na próxima seção, passa a ser a garantia da ordem e, ao mesmo tempo, do crescimento do Estado. A palavra bemestar passa a ser utilizada com frequência, portando um novo sentido no conjunto de leis e regulamentos que possam garantir o bom uso das forças do Estado. A pesquisa de Foucault (2008) demonstra que a palavra bem-estar, melhor que as palavras comodidade, felicidade, designa aquilo de que a polícia se ocupa, pois "tudo o que vai do ser ao bem-estar, tudo o que pode produzir esse bem-estar para além do ser e de tal sorte que o bem-estar dos indivíduos seja a força do Estado, é esse, parece-me, o objetivo da polícia" (FOUCAULT, 2008, p. 440).

O efeito do investimento do corpo pelo poder trabalha no sentido das conquistas, dos desejos de seu próprio corpo pelos indivíduos por meio de uma luta insistente, obstinada, meticulosa. A partir do momento em que o poder produziu esse efeito de conquista de um investimento, "emerge inevitavelmente a reivindicação de seu corpo contra o poder, a saúde contra a economia, o prazer contra as normas morais da sexualidade, do casamento, do pudor" (FOUCAULT, 2014, p. 259). Para ilustrar essa constatação, Foucault apresenta um exemplo, que pode ser estendido a várias práticas de nosso presente, mostrando como o medo instaurou sobre os corpos dos indivíduos um controle, uma vigilância da sexualidade com uma perseguição dos corpos, mas também como a sexualidade, tornando-se, assim, um objeto de preocupação e de análise, gerou ao mesmo tempo a intensificação dos desejos por, em e sobre seu próprio corpo. A revolta do corpo sexual é o contraefeito do avanço desse controle.

Como responde o poder? Por uma exploração econômica [...] da erotização, desde os produtos de bronzeamento até os filmes pornôs... Como resposta mesmo à revolta do corpo, você encontrará um novo investimento que não se apresenta mais sob a forma do controlerepressão, mas sob a do controle-estimulação: 'Fique nu... mas seja magro, bronzeado!' (FOUCAULT, 2014, p. 259-260). 
O investimento sobre os efeitos e os contraefeitos do controle-estimulação não cessa de ser operado por meio da provável eficácia dos saberes sobre o produto não desejado, fazendo com que regimes diferentes e heterogêneos marquem os corpos da população e as formas de estar no espaço urbano. Pensar a cidade e seus corpos hoje com base nessa formulação de Foucault sobre o tipo de poder que vai se configurando a partir do século XVIII pode parecer sem fundamento, contudo o autor oferece a chave de entrada para uma análise da atualidade com a questão de que devemos nos perguntar: qual corpo a sociedade precisa. Ao falar sobre o tipo de investimento do corpo necessário e suficiente para o funcionamento de uma sociedade capitalista, Foucault (2014) explica que, do século XVIII ao início do século XX, acreditou-se que o investimento do corpo pelo poder devia ser pesado, vigoroso, constante, meticuloso, mas, a partir dos anos de 1960, perceberam que esse poder tão rígido não era mais indispensável e que as sociedades industriais podiam contentar-se com um poder sobre o corpo mais solto, com os controles ganhando outras formas mais atenuadas.

Dessa forma, acreditamos que as estratégias do biopoder e a análise do funcionamento dos dispositivos de saber/poder, tão cuidadosamente estudadas por Foucault, colocam luz sobre as práticas discursivas e não discursivas, possibilitando a visualização da rede que configura os saberes e as condições de política e de verdade do dispositivo que, por ser de natureza estratégica, entrelaça em seus mecanismos os corpos da população e os arranjos das ruas da cidade, compondo regras sempre renováveis que subjetivam pelos seus efeitos e objetivam pelas suas tecnologias. Nessa relação entre técnicas de objetivação e práticas de subjetivação, não se deve deixar de considerar que a liberdade, para Foucault, é condição da existência do poder, que não pode ser exercido sem uma resistência, sem uma eventual inversão. Considerando essa produtiva relação, podemos pensar no ato de circular na cidade e problematizar o ato de conduzir como o modo de

se comportar num campo mais ou menos aberto de possibilidades, onde o poder aparece conduzindo as condutas num espaço que o sujeito precisa se sentir livre, liberto; lugar esse, onde as práticas o capturem e façam com que o sujeito tenha uma resistência não maior do que a constância das práticas do dispositivo (STASSUN; ASSMANN, 2010, p. 87).

Assim, o dispositivo promove não um confronto entre pessoas que, no final, um sairá vitorioso, mas sim um jogo de relações antagônicas, jogo esse permanente, fluido, com mecanismos estáveis que exigem graus de liberdade, dados pela forma de intervenção biopolítica reduzida sobre a conduta das pessoas. A resistência, como os enunciados, é da ordem do acontecimento, pois se liga a certas condições de possibilidade que permitem a emergência dos discursos de recusa, revolta, dissidência, contra-conduta ou de transgressão. A imagem ${ }^{1}$ (figura 1) abaixo circulou recentemente no Facebook como um exemplo (ou apelo) de que é possível resistir a um domínio atual de poder. Contudo, os prédios da fotografia já existiam na paisagem de uma rua da cidade de Palmas/To, mas não existiam ainda como discurso de resistência. O discurso da resistência emerge como um acontecimento singular, uma irrupção no tempo, marcado por uma multiplicidade de relações discursivas já manifestas em confrontos políticos entre a bancada da ala evangélica e a da ala dos direitos humanos do

\footnotetext{
${ }^{1}$ http://portalamazonia.com/noticias-detalhe/cidades/situado-entre-duas-igrejas-bar-do-araujo-vira-memee-ganha-fama-em-palmas/?cHash=89bcd3d14f1630d856358be00652a813
} 
Congresso Nacional; e uma irrupção no espaço, ocupado pela rede social Facebook, uma ramificação de outros espaços, do real visível da cidade e do discursivo das plenárias do poder legislativo. É esse arquivo, nos termos de Foucault, constituído de práticas discursivas e não discursivas que faz com que os fatos antagônicos ditos se mantenham, que as resistências insurjam de forma móvel, com desenhos que seguem o traço das produções discursivas já dadas, ganhando visibilidade em sua emergência nas relações de enfrentamento em condições de possibilidades específicas.

A resistência do bar do Araújo, colocado entre duas igrejas evangélicas, personifica o sujeito que deve lutar contra a sujeição, a captura, a opressão, e pelo direito de ter garantido um espaço na cidade. Como na relação poder e resistência, o bar, ao se colocar como único no espaço de prevalência das igrejas, reforça o exercício do poder, garantindo a manutenção do dispositivo, que tem sempre mecanismos para reduzir a resistência, sem que haja supressão da liberdade. A possibilidade de escolha produz a sensação de liberdade e naturaliza a vitória como conquista daquele grupo que sofreu a resistência.

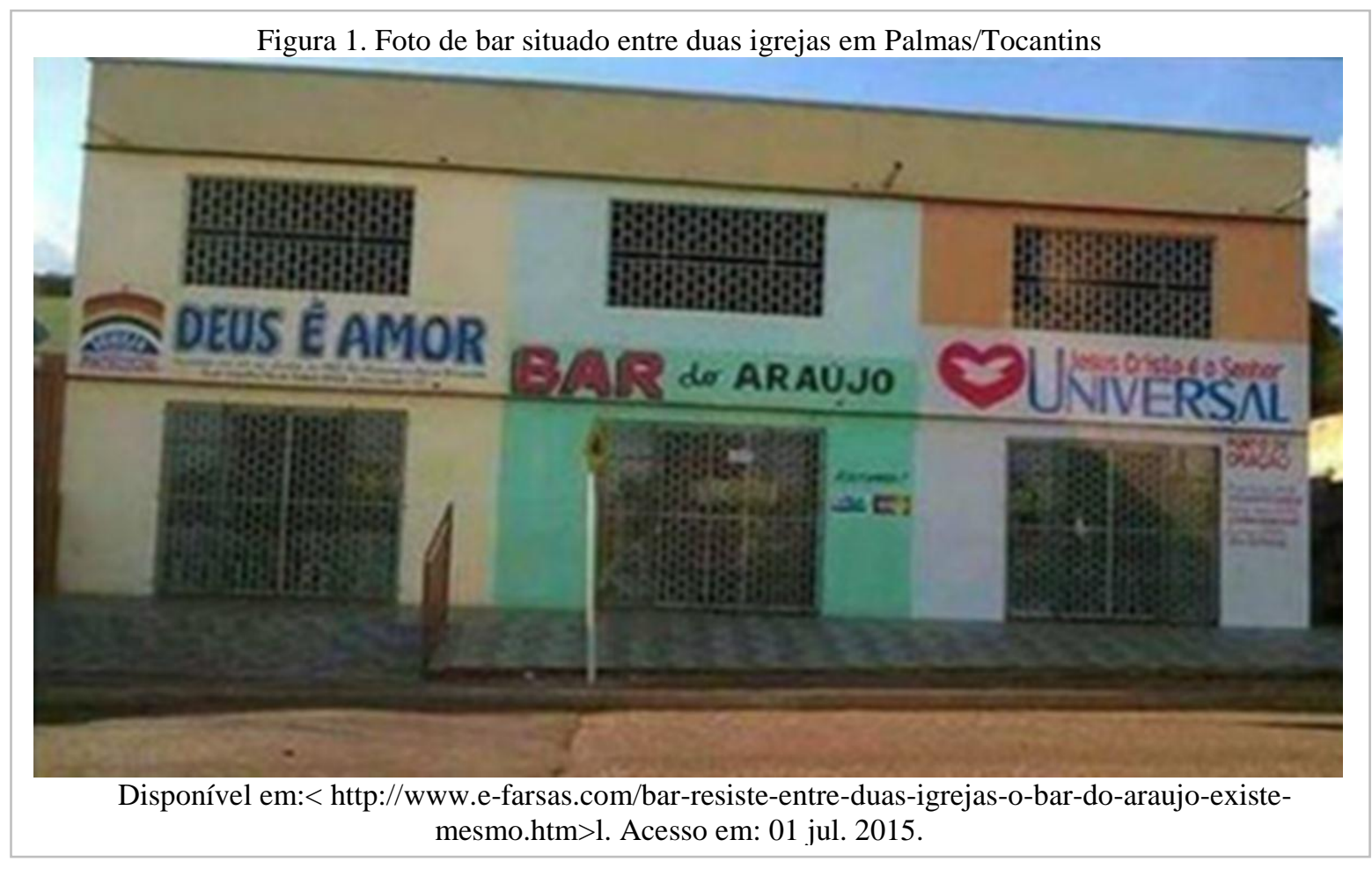

A cidade, assim, configura-se como um espaço que acolhe toda a população, que permite a liberdade de escolhas desde que ajustadas ao sistema que garante o bem-estar dessa população num nível aceitável, pois ela aparece no dispositivo "tanto como objeto, isto é, aquilo sobre o que, para o que são dirigidos os mecanismos para obter sobre ela certo efeito, [quanto como] sujeito, já que é a ela que se pede para se comportar deste ou daquele jeito" (FOUCAULT, 2008, p. 56). Nesse sentido, o povo, conforme Foucault, aparece como sendo aquele que resiste à regulação da população, que tenta escapar desse dispositivo pelo qual a população existe, se mantém e subsiste num nível ótimo.

O bar do Araújo aparece nas manifestações contrárias ao domínio dos preceitos morais religiosos como representação do povo que vai ganhando um novo ordenamento nos espaços da cidade, por força do dispositivo político religioso, e sendo empurrado para fora do esquadrinhamento desenhado pelas práticas que prometem um bem-estar 
mais durável e salvacionista. O poder aparece conduzindo os sujeitos num espaço em que eles precisam se sentir livres, onde as práticas possam capturá-los ou os levarem à resistência, mas uma resistência não maior do que a constância das práticas do dispositivo. Assim, o espaço delimitado da cidade entra numa rede enunciativa, não como um documento da localização dos prédios, mas como monumento a integrar outros dispositivos. Como monumento passa a compor diferentes cenários e enunciados que respondem a algo antes e que suscitam outros enunciados como o do post (figura 2) publicado no Facebook: "Resista, Araújo!". Araújo é o corpo que não aceita se moldar conforme as normas que asseguram a saúde, a longevidade, os bons costumes da moral cristã, a vida eterna. Mas é um corpo que se encontra acuado, cercado, sozinho, sem espaço para a luta diante do contingente da população que assina o contrato com o dispositivo.

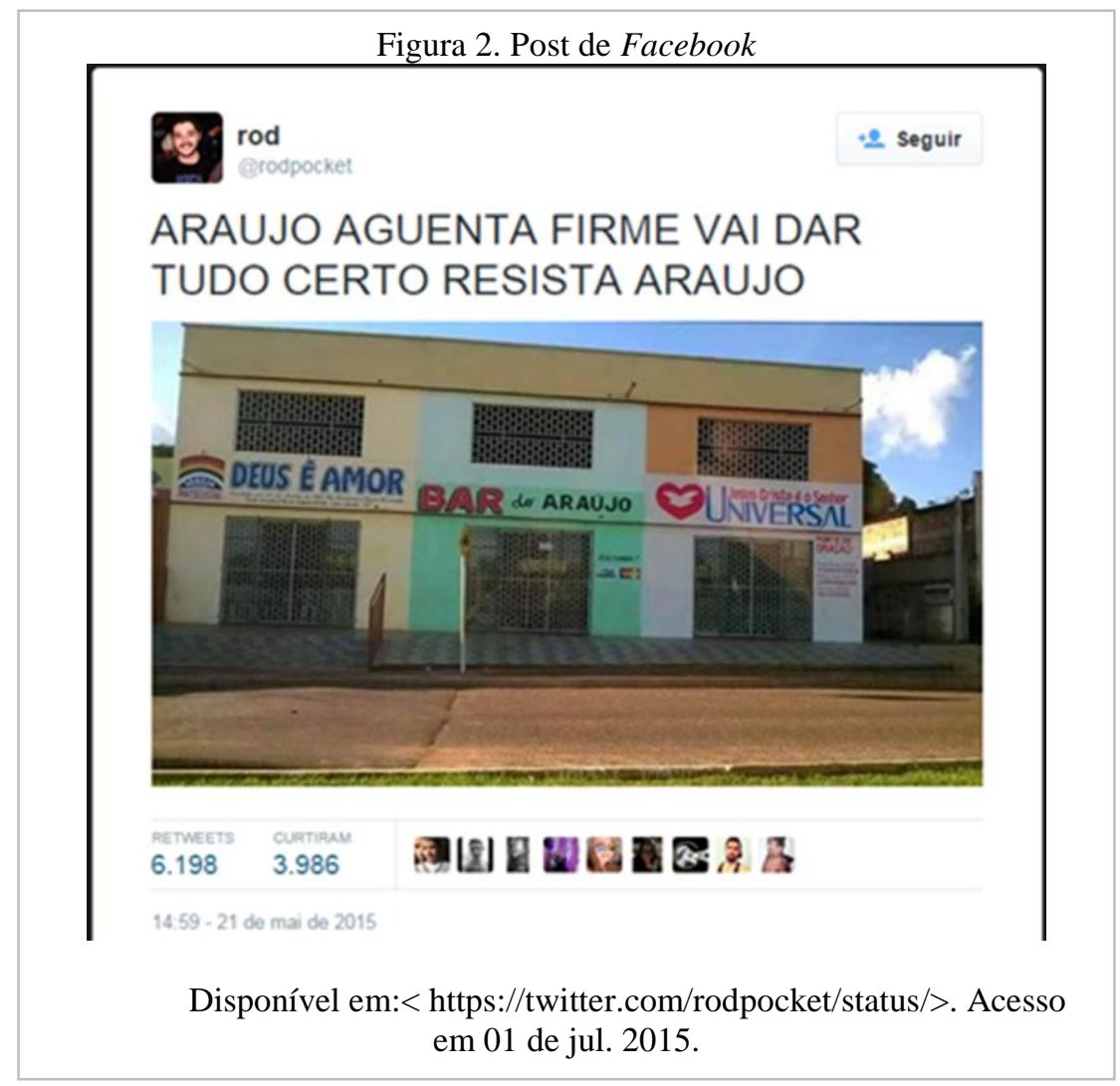

\section{A percepção do corpo: do ser, ao saber e à ação}

Em recente publicação denominada Le sentiment de soi. Histoire de la perception du corps, George Vigarello (2014), especialista em história das práticas corporais e das representações do corpo, coloca em pauta como a sensação de bem-estar passa de uma tradição na qual o sentimento de si estava, até o século XVIII, na Europa, atrelado ao pensamento e ao espírito, para uma nova perspectiva desencadeada pelo Iluminismo.

A tradição apresentou-nos os sentidos corporais como externos. A audição, a visão, o tato, o odor e o gosto aguçam-se a cada vez que se quer prevenir o corpo das ameaças externas e assim eram vistos os cinco sentidos. Do exterior para o interior os sentidos tinham o papel de informar a alma dos acontecimentos do mundo 
(VIGARELLO, 2014). Na história da sociedade ocidental, o reconhecimento das impressões sensoriais internas é tardio. Sentir-se, interrogar a si mesmo sobre suas sensações, dar importância às experiências recolhidas, apropriar-se de seu próprio corpo, reconhecendo-lhe seus direitos, configuram um universo somente possível com as transformações advindas com o período das Luzes. A idade da razão afasta os misticismos, o valor único e central da alma e permite que se possa ouvir o interior do corpo, o desejo. Conforme Vigarello (2014, p. 11) $)^{2}$ : "Expressões são inventadas [...] para valorizar o 'sentimento de existência', o 'sentimento de si', o 'sentimento de identidade', instalando a fonte do reconhecimento íntimo no cruzamento do físico e da moral e não mais na simples consciência 'ideal' de si'.

Se na idade clássica ignorava-se o interno do corpo e de seus sentidos em função unicamente do externo; o século XVIII dá voz ao campo sensorial, inaugura o corpo menos dependente do sobrenatural, menos atravessado pelo divino e mais fortalecido por sua autonomia. Uma nova imagem se faz do corpo. São, então, os nervos, tomados como um circuito elétrico que se lança a todas as partes do corpo, que fazem emergir o sensível, revelando o universo de palpitações e vibrações.

Essa percepção do corpo produz modificações nos discursos, sentimentos íntimos antes não revelados passam à ordem do dizer. Expressam-se, no cotidiano, perturbações do ser, mal estares vagamente identificados. "O interno do corpo se desloca, satura os instantes, dá densidade às excitações subterrâneas, acompanha a vida do indivíduo até não mais poder dele se distinguir" (VIGARELLO, 2014, p. 60) ${ }^{3}$. As atividades como banhar-se em água morna, antes fonte mecânica dos fluxos, passa a ser desfrutada como ação que causa efeito sobre os nervos, ela "faz 'abrir as expansões nervosas', causa 'uma sensação de volúpia indizível"” (VIGARELLO, 2014, p. 61) ${ }^{4}$. A água e o banho, antes referência do externo sobre o corpo, passam a ser objeto de análise, de curiosidade, associados às percepções de sentimento. Entra na ordem discursiva privilegiar as sensações. Em um momento em que se desenvolve o conhecimento a respeito da eletricidade, o termo 'tensão', ocupa lugar de destaque, sobrepondo-se aos fluxos. As tensões, as enervações, diante dos sentimentos de opressão, de ansiedade, de contrariedades, contraem-se em um circuito, produzindo um 'ataque de nervos'. Expressão que passa a ser usual, sustentando as mutações discursivas.

A cidade passa a fazer parte do registro desses sentimentos. Seja na Europa, ou no continente americano, o movimento de migração invasiva do campo para a cidade, devido à industrialização, à profissionalização, às exigências citadinas, expõe os sujeitos a confinamentos, a novas formas de consumo, enfim a tensões inevitáveis que atingem o corpo, então indiviso de si mesmo. Surge um indivíduo invadido pelo corpo. "Através do 'sentimento de existência', o Iluminismo renovou o 'sentimento de identidade'. As Luzes inventaram um modo particular de investimento de si, uma maneira de circunscrever o indivíduo pelo que sente fisicamente e não idealmente" (VIGARELLO, 2014, p.85) ${ }^{5}$.

\footnotetext{
${ }^{2}$ Des expressions également s'iventent [...] pour valoriser le 'sentiment de l'existence', le 'sentiment de soi', le 'sentiment l'identité', installant la source de quelque reconnaissance intime dans le croisement du physique et du moral et non plus dans la simple conscience 'idéelle' de si.

${ }^{3}$ L'interne du corps se déplace, sature les instants, donne une densité aux excitations 'souterraines'accompagne la viedu l'individu jusqu'à ne plus pouvoir s'en distinguer.

${ }^{4}[\ldots]$ elle 'épanouitles expansions nerveuses', cause 'une sensation de volupté indicible'.

5 À travers le 'sentiment de l'existence', les Lumières ont em fait renouvelé le 'sentiment de l'identité'. Elles ont inventé um mode particulier d'investissement di soi, une manière de circonscrire l'individu à travers ce qu'il ressente physiquement et non idéellement.
} 
O século XIX é, então, o período de busca dos saberes. Não se trata mais de descobrir o 'sentimento de existência', mas de pesquisar e compreender como as impressões orgânicas, as sensações do corpo possuem relações com o corpo físico, observado pelas ciências médicas em expansão. Mas neste jogo não está somente presente o saber médico sobre o interior do corpo; novas prospecções fazem surgir as primeiras notas da psicologia, na busca da compreensão do sentimento interno.

A sensibilidade interna ganha, enfim, no início do século $\mathrm{XX}$, mais espaço, sobretudo ao ser reconhecida na esfera do psíquico. Já não é somente a percepção externa e seus cinco sentidos que regem os saberes, nem mesmo a percepção interna, apreendida para orientar os corpos para melhor perceber as coisas e os objetos. É o conjunto do corpo que passa a ser observado em um intercâmbio entre o organismo e seu meio (VIGARELLO, 2014).

As sensações internas passam a ter nome, são captadas graficamente em curvas e riscos (a exemplo dos exames cardíacos), produzindo uma visibilidade do interior e possibilitando com isso patologizar um inventário do sensível. Os sentimentos de bemestar ou de mal-estar passam a ser também fonte de pesquisa da psicologia, que os estuda na articulação do consciente com o inconsciente. Tanto no âmbito da medicina, quando da psicologia vê-se uma tentativa de descrever, detalhar e classificar uma dispersão de sentimentos. Nesse jogo entre o externo e o interno, o avanço dá-se com o aprofundamento das questões sobre a sensação corporal. Com isso, observa-se que a emergência do psíquico, desse saber, instala uma esfera no qual os dados corporais, articulados aos sentimentos fazem surgir projetos de ação sobre si. A sensibilidade é vista como uma totalidade e assim abre margem para uma extensão ilimitada do sensível.

É no cruzamento das reflexões até aqui apresentadas, que queremos apontar como se podem analisar as relações que se estabelecem entre a cidade e os sentimentos de identidade. Conforme as reflexões de G. Vigarello (2014), não se trata mais de um 'sentimento de si', de um reconhecimento fundado na proposição "Penso, logo existo". Passa-se à centralidade das articulações entre o interno e o externo, possibilitada pela invenção do corpo. "Eu sinto, logo existo" sustenta a ideia de que podemos agir sobre o nosso humor e sobre os estados da alma por um trabalho sobre o corpo. Se neste percurso histórico do ser passa-se ao saber, o terceiro momento conduz à ação.

A cidade produz excitações neste universo do sensível que ao longo do tempo se modifica e se acentua. Se, no fim do século XIX na Europa e início do século XX no Brasil, era o princípio do processo de industrialização que com ele trazia os sedentarismos, os confinamentos exigidos pelo trabalho em larga produção industrial, a exaustão do operário, vemos que ao longo do século isso se acentua, levando o corpo a seus mais fortes impactos, seja pelo acúmulo dos fluxos sensoriais, seja pelo excesso de estímulos. A vida urbana com seus barulhos incessantes, com trepidações nos deslocamentos, com um fluxo contínuo de luzes e de sons provoca efeitos multiplicadores no corpo. "Uma palavra é inventada para traduzir esse novo mal: estresse" (VIGARELLO, 2014, p. 194) ${ }^{6}$. Os movimentos das cidades interferem nos humores. E se inicia, então, um movimento de relaxamento e de exercícios ritmados, de distração e de autossugestões. Isso se dá por processos de objetivação e subjetivação.

$\mathrm{Na}$ sequência, nosso propósito é recensear e analisar como a cidade e suas formas de expressão presentes nas ruas, nas praças, nos slogans distribuídos nos mais diversos pontos da cidade dirigem-se a esse corpo sensorial, indicando-lhe as ações e

\footnotetext{
${ }^{6} \mathrm{Um}$ mot est inventé pour traduire le mal nouveau: celui de 'surmenage'.
} 
atingindo, das mais diversas formas, essa intimidade sensível ao mesmo tempo em que atinge a população.

\section{O discurso da cidade em nós: é pelas ruas que as sensibilidades são atingidas, é pelo biopoder que o corpo é adestrável}

Não importa se se trata de um passeio tranquilo pelas ruas da cidade ou de um deslocamento rápido de um ponto a outro; de toda forma a nossa exposição à cidade logo invade nossas sensibilidades. As cidades, tomadas como espaço urbano de circulação, são também fonte de controle dos corpos. A noção de 'meio', conforme reflexão de M. Foucault (2008), responde pela espacialidade das sociedades biopolíticas, sendo o domínio da circulação uma ação sobre a sociedade que atua tanto de forma positiva, por caracterizar-se de um recurso que vem a estimular os fluxos econômicos, como de forma negativa, uma vez que tem por princípio exercer o controle sobre essa sociedade. A relação intrínseca e direta entre o 'meio' e a população torna o espaço urbano um espaço de controle.

Nas sociedades biopolíticas, há uma expectativa de que o Estado assegure o crescimento e garanta o bem-estar dos indivíduos. Nossos passeios pela cidade fazemnos suspeitar que, neste início de século, as formas de controle são exercidas sobre a população, atuando em um exercício sutil de forma a atingir a sensibilidade corporal de cada um dos seus cidadãos. A fim de organizar nossos argumentos, consideraremos, a partir de Foucault, como se dá o funcionamento das quatro funções que, atuando em uma rede, em uma forma de dispositivo, asseguram a relação do Estado com a população e de uma forma específica como isso se articula com a percepção do corpo na contemporaneidade.

\subsection{Higiene corporal e mental: a percepção do corpo limpo}

As medidas de higiene há muito fazem parte das exigências de uma sociedade. A nomeação higiene corporal sugere práticas de manutenção da saúde do corpo obtida pelo banho, escovação dos dentes, etc., mas hoje a cidade objetiva-nos 'impuros corporais', ao nos sugerir programas de tratamento como, por exemplo:

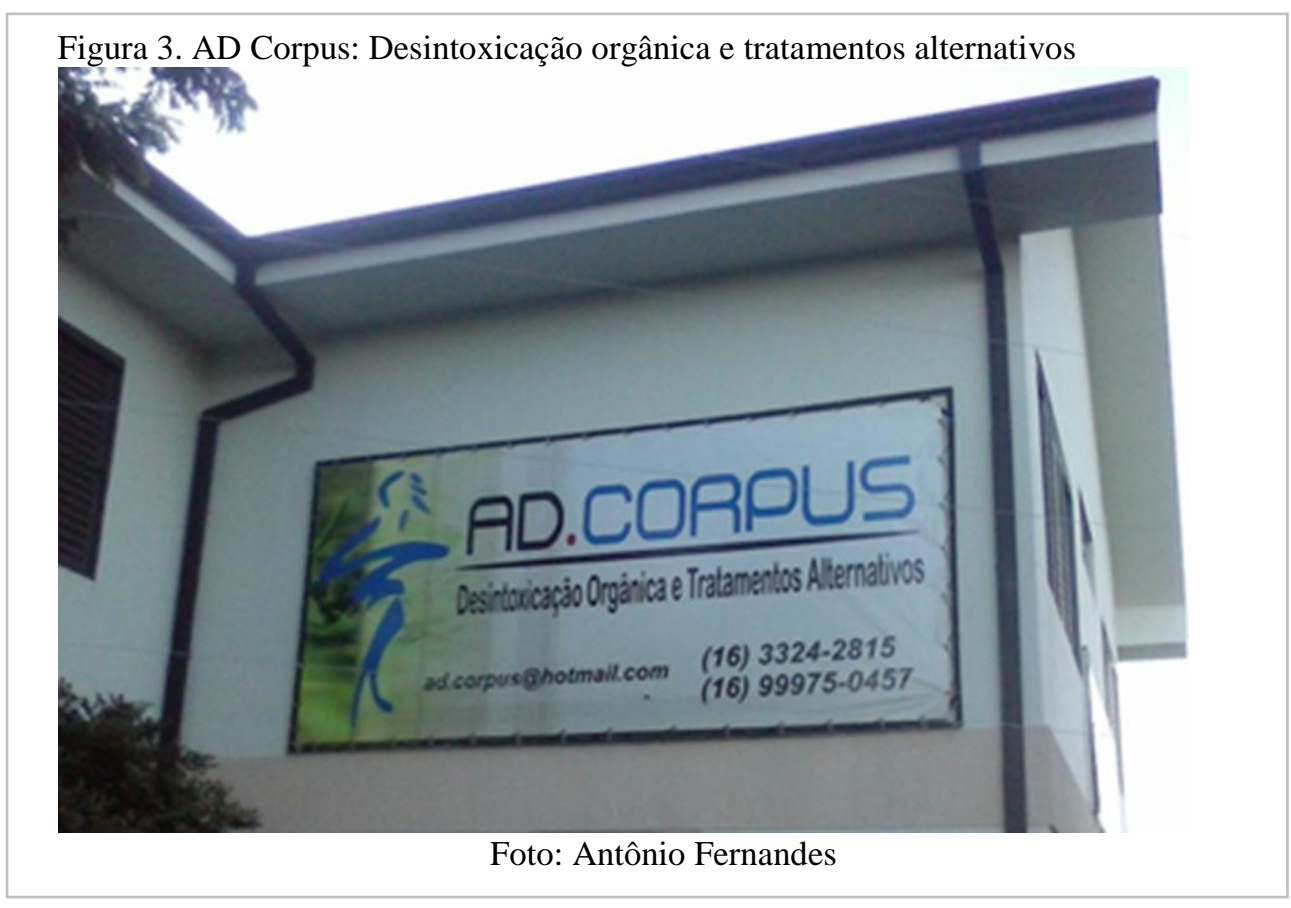


A objetivação do sujeito como aquele que deve passar por uma limpeza corporal é visível não só em clínicas de tratamento, mas também em restaurantes. De forma esquadrinhada, o sujeito passa por um processo de subjetivação de ser impuro e é levado a crer que nas mínimas e cotidianas ações é possível atingir um corpo puro. Como exemplo, citamos o cardápio de um restaurante (figura 4) especialista em 'steak' que exibia em sua sessão de sucos, dentre outros, os seguintes: - Desintoxicante (melancia, gengibre e água de coco), Pele Hidratada (morango, água de coco), Bem estar (power clorofila), Antioxidante e tonificante (abacaxi, laranja e colágeno em pó).

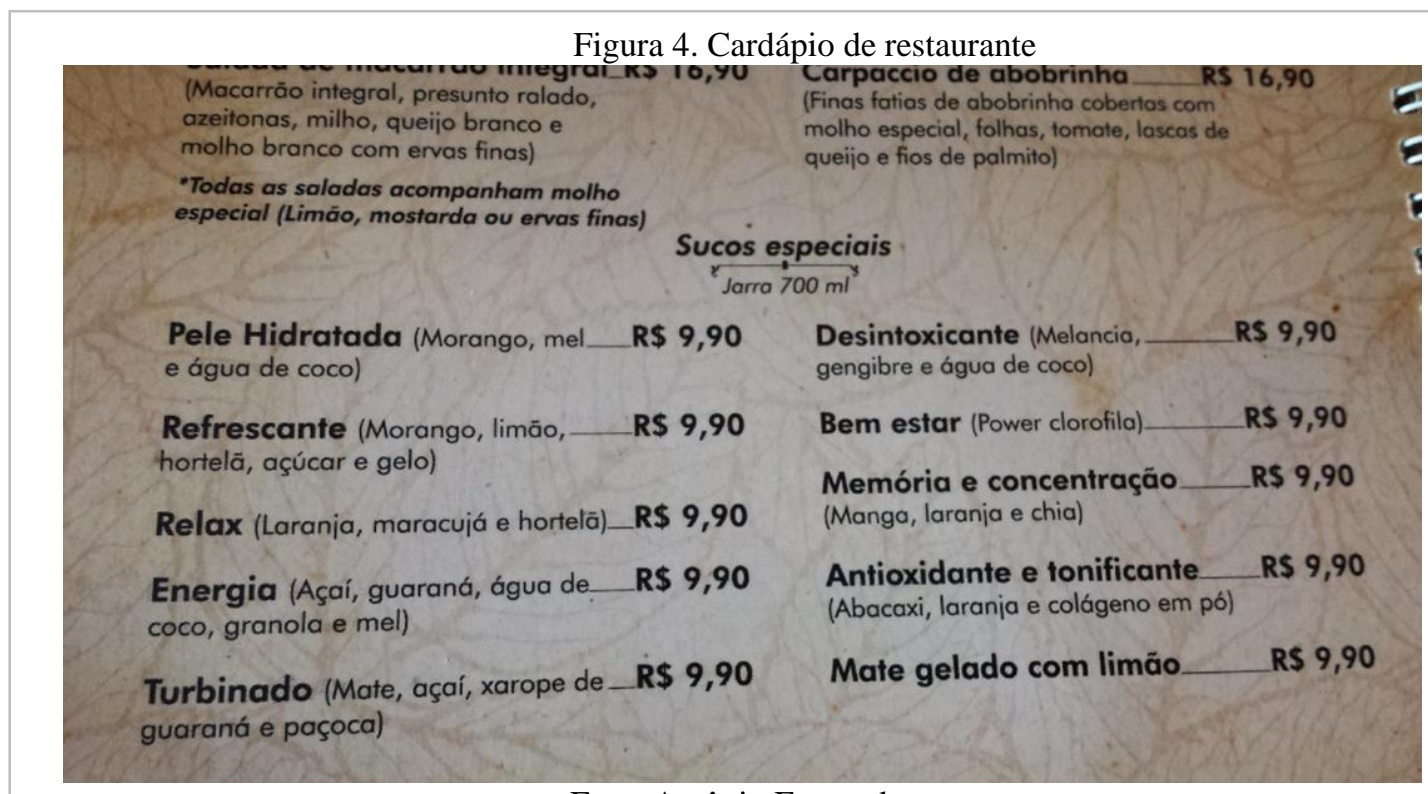

Foto: Antônio Fernandes

A denominação atribuída aos sucos associam os sentimentos internos de bem estar e de relaxamento ao consumo de alimentos que nutram o corpo. Os ingredientes que compõem o suco não são arrolados como informação principal, eles estão entre parênteses, como um dado adicional, e consideremos que o nome principal poderia ser encontrado, com essa mesma expressão lexical, em embalagens de remédio. A indistinção entre o alimento e o medicamento (desintoxicante), entre o alimento e o sentimento (bem estar, memória e concentração, energia), entre o alimento e a ação sobre o corpo físico (pele hidratada, antioxidante e tonificante) inscreve o sujeito na ordem discursiva do saber e da ação sobre o corpo, condicionando o bem estar à saúde do corpo físico. Essas formas de expressão dispersas pela cidade, seja em outdoor, placas em casas de comércio, folders de propaganda, etc., atuam como um processo de subjetivação do sujeito e traçam biopolíticas que garantem as relações entre o Estado e a população.

O sentimento de 'bem estar' também está associado às ações corporais fundamentais e o discurso de controle da sociedade sobre os indivíduos começa no corpo e com o corpo. A biopolítica atua de forma variada nos mais diversos e mínimos lugares. Os suportes são revistas, programas de TV, materiais de instrução, produzidos para orientar o sujeito. Isso tudo reafirma como o sentimento de si, na contemporaneidade, articula-se ao 'sinto, logo existo'. O bem-estar, a paz, a energia, o amor, a felicidade adornam graficamente as paredes envidraçadas de uma farmácia. Um indício de que tudo isso pode ser adquirido ali? Talvez, se partilharmos deste exitoso discurso do século XXI, de que os sentimentos encontram guarda no corpo físico. 
O lazer, por sua vez, também se dá articulado às noções de higiene. A cidade passa a oferecer, com valor eufórico, os espaços marcados por uma biopolítica do consumo de alimentos orgânicos, que por extensão garantirão a 'limpeza da plantação' e a 'pureza corporal'. No exemplo a seguir (figura 5), a proposta da Eco hospedagem, indica que a associação com um bom roteiro de viagem passa pelo consumo de produtos orgânicos.

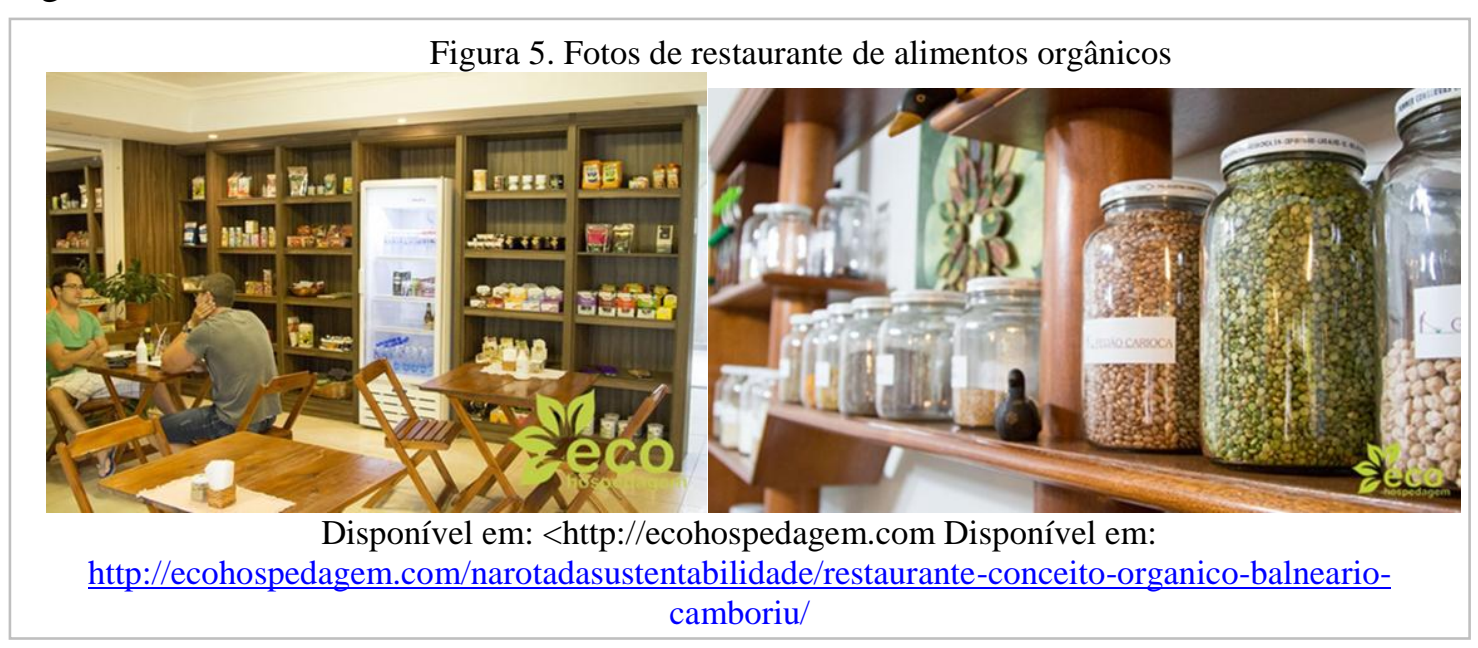

Há em todos esses exemplos relações entre dispositivo de segurança e corpos dos indivíduos organizados conforme as funções que lhe são asseguradas pelo espaço onde circulam; a cidade. Como resultado dos saberes que são difundidos de forma midiática, histórica e social, os sujeitos são objetivados por esses saberes e ficam suscetíveis às relações de poderes que atuam por técnicas de subjetivação. Trata-se de objetivar-se 'impuro', intoxicado pelos fluidos urbanos, pelos alimentos produzidos em larga escala, impregnados de agrotóxicos; para então, iniciar um processo de subjetivação que atua ao mesmo tempo de forma dispersa e intensa nos mais diversos pontos da cidade. O cardápio de um restaurante, as vitrines de uma farmácia, os espaços de lazer. São práticas discursivas que sustentam a biopolítica.

\subsection{A circulação de mercadorias: o corpo, um bem a ser mantido}

O dispositivo de segurança, que vai se construindo com o processo de urbanização, deve assegurar, também, tanto a circulação de mercadorias quanto a circulação de pessoas, eliminando o que é perigoso e separando a boa circulação da má. Conforme Foucault (2008), por circulação deve-se entender não apenas a rede material que possibilita a circulação das mercadorias e dos homens, mas a própria circulação, com seu conjunto de regulamentos, imposições, limites, mas também as facilidades e os incentivos que possibilitam a circulação dos homens e das coisas. A circulação depende de objetos urbanos, já que só existem nas cidades, como as ruas, as praças, os edifícios, o mercado, o comércio, as manufaturas etc. Há outros objetos que são problema, como a escassez alimentar, a presença de mendigos, a circulação dos vagabundos.

Os problemas da cidade e dos corpos nela distribuídos são também problemas de mercado, com a organização das relações entre uma população e a produção de mercadorias que surgem com o que Foucault (2008) vai denominar por emergência da cidade-mercado, com todos os problemas de coabitação, de circulação, vigilância, que vai se tornando o modelo de intervenção estatal na vida dos homens. Trata-se de todo um problema relativo à coexistência dos homens e à circulação das mercadorias. Sob a influência das estratégias da biopolítica e do dispositivo de segurança, a cidade trabalha 
sobre algo dado, como se estivesse sempre em desenvolvimento, maximizando os elementos positivos, melhorando da melhor forma possível a circulação e minimizando o que é risco e inconveniente. A cidade deve lidar com probabilidades, com a polifuncionalidade de seus elementos e com o planejamento futuro que leve em conta o que pode acontecer. A segurança, conforme Foucault (2008, p. 27), procura "criar um ambiente em função de acontecimentos ou de séries de acontecimentos ou de elementos possíveis, séries que vai ser preciso regularizar num contexto multivalente e transformável". Esse ambiente, ou espaço, é que Foucault chama de meio, ou seja, aquilo em que se faz a circulação.

Se observarmos os espaços de circulação de mercadorias e de pessoas nas grandes cidades, constatamos facilmente a existência de territórios democráticos, cuja função é a captura de todos os corpos da população, atendendo a diferentes formas e possibilidades de circulação e consumo. Nas imagens a seguir (figuras 6 e 7), temos dois espaços de circulação e de consumo, que de início se apresentam como paradoxais, estabelecendo o corte entre o popular, para os menos favorecidos, e o sofisticado, para aqueles com poder aquisitivo maior. Essa questão inicial é indiscutível, mas não explicita o funcionamento do dispositivo em relação à circulação. Ele procura atingir a população como um todo, uma multiplicidade de indivíduos, produzindo a percepção de resistência à dificuldade imposta pelo capitalismo para a aquisição de bens de consumo e de se poder integrar a circulação e de adquirir mercadorias da moda e dos avanços tecnológicos. Essa percepção garante o funcionamento do dispositivo, pois ela entra como causa do bem-estar, da liberdade de ir e vir, de consumir e lucrar, da felicidade. Esses efeitos tanto garantem a manutenção das práticas do dispositivo, quanto funcionam como técnicas de subjetivação, que reconhecem como feliz aquele sujeito que circula, compra e consome. Se a maioria não pode frequentar o espaço sossegado do comércio requintado, a cidade oferece outras opções para que a população tenha seus desejos realizados e ainda se sinta como atendido em suas escolhas.

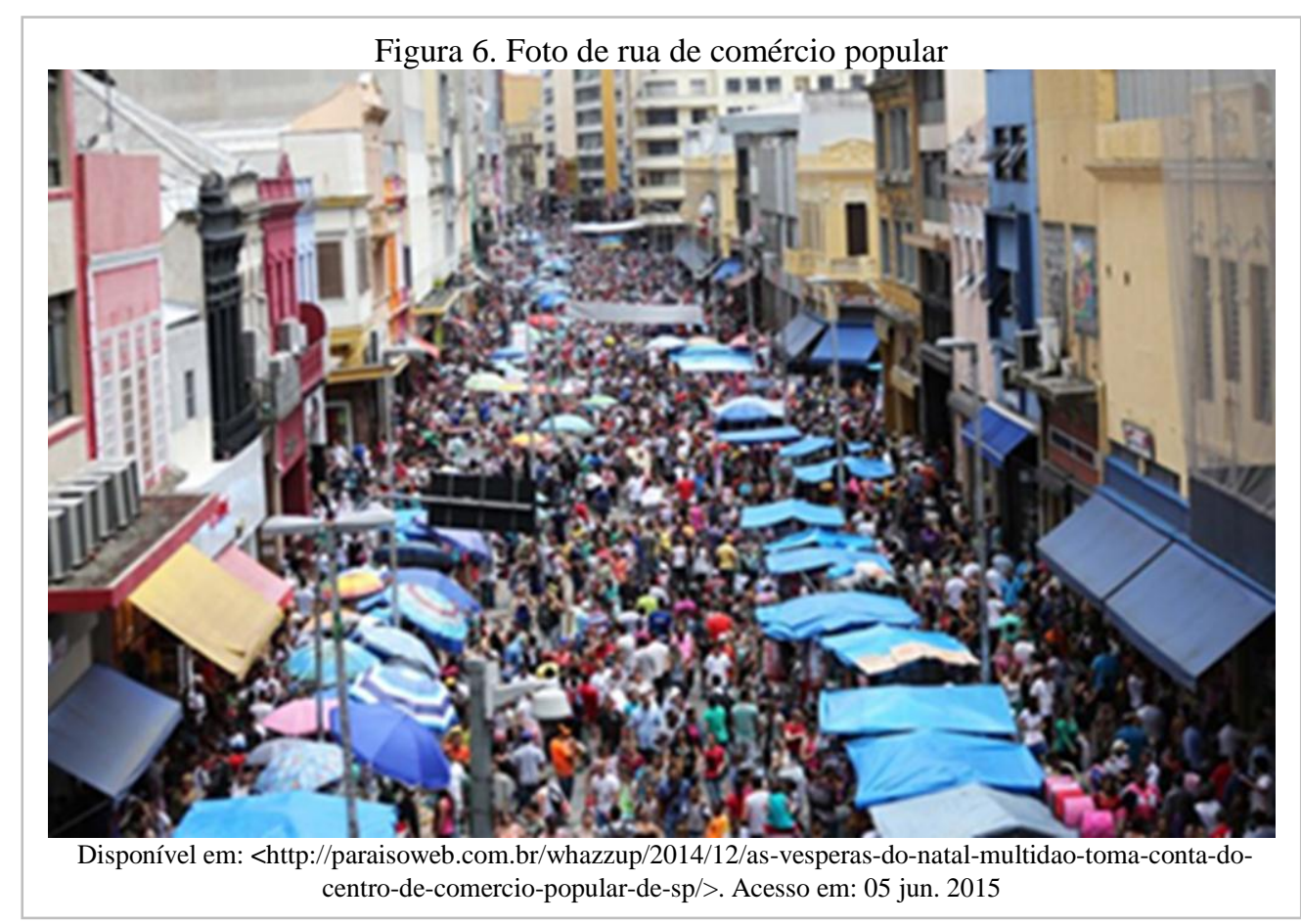




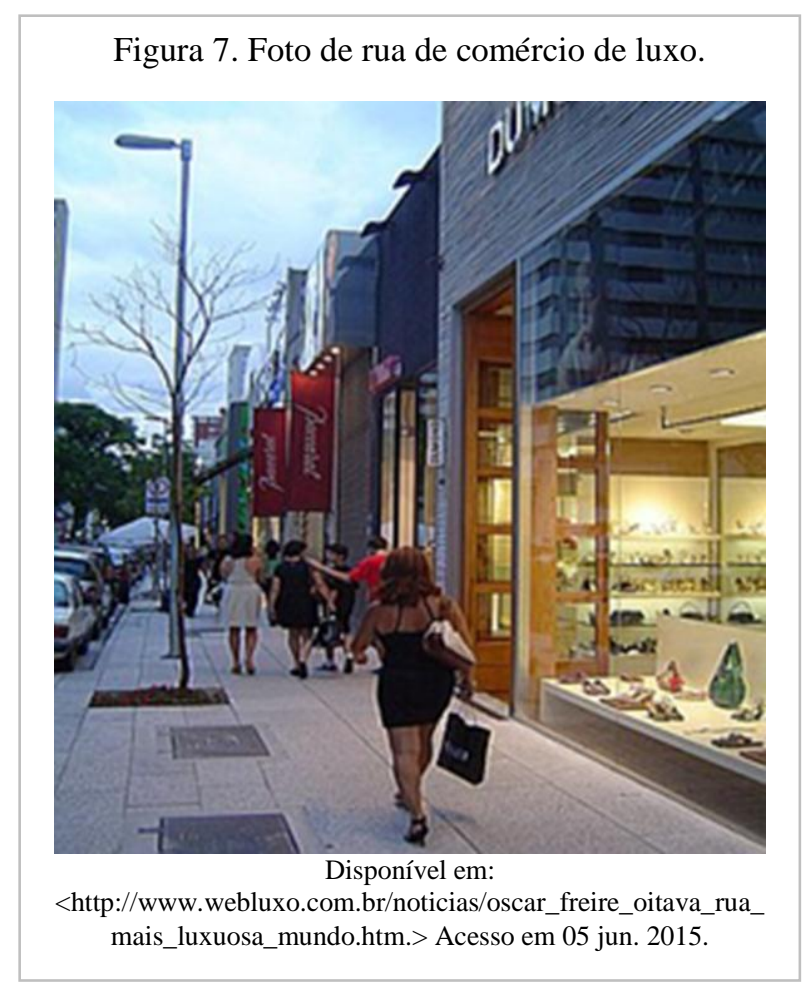

A diversificação dos espaços da cidade para garantia da circulação, do consumo, do lucro e da felicidade geral não cessa de se modificar conforme as urgências dos problemas que vão surgindo. Aliás, essa é a função fundamental do dispositivo: atender as urgências, contornar os problemas. Também relacionado à cidade de São Paulo, como as imagens acima, fomos informados recentemente que "Ciclovias de Haddad são premiadas nos Estados Unidos" (figura 8). Conforme a notícia, "a premiação é concedida a cidades que implementam projetos de transporte considerados inovadores e sustentáveis". A questão colocada, ao integrar um dispositivo, se conecta a outros temas, que não só a circulação de pessoas, mas que dizem respeito a outros problemas que estão na ordem do momento, como a sustentabilidade e a modernização constante. A imagem que acompanha a notícia apresenta uma configuração possível para o ato de se movimentar nas cidades de forma a atender às demandas da obrigação de circular, consumir e lucrar, e das prescrições para alcançar o bem-estar por intermédio do controle da poluição, da organização do trânsito, do exercício físico e da economia pessoal e coletiva.

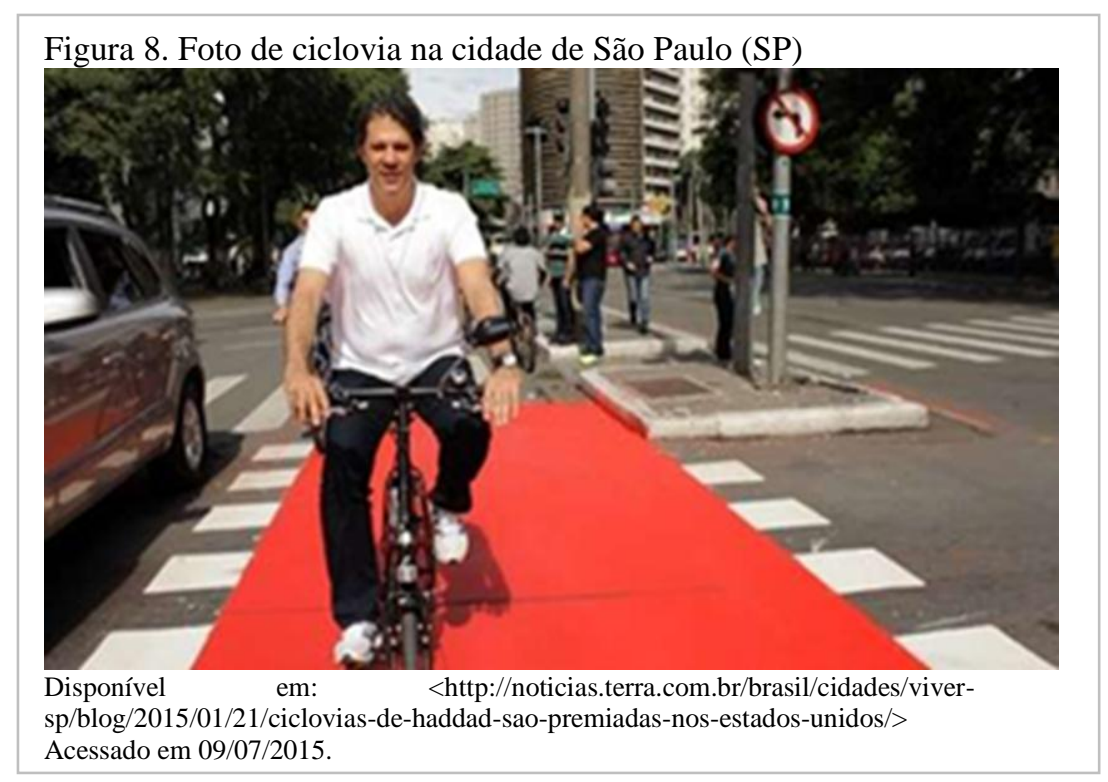




\subsection{A segurança do corpo: o medo da morte e do tempo}

Os dispositivos de segurança surgem para dominar os medos que afligem a população das cidades. Se uma das formas de contenção desse medo, como vimos, é o controle da circulação, por outro lado o medo da morte também leva a buscar evitar doenças contagiosas e tende a valorizar o cuidado com o corpo, em um exercício insistente que supostamente o conduza à boa saúde (FOUCAULT, 2014).

A ginástica, o desenvolvimento muscular, o controle e mensuração dos exercícios passam a fazer parte da cidade. As praças com demarcações em seu piso definem quantos metros se caminhou, os aparelhos para idosos se exercitarem nas praças os objetivam sedentários e os chamam ao exercício, em um processo de subjetivação que expõem o modelo da saúde como aquele a ser perseguido.

Pululam academias nos mais diferentes pontos da cidade, chamando o sujeito aos exercícios funcionais, às atividades corporais, às diversas técnicas de defesa pessoal, cada uma dessas com suas denominações específicas - Cross Fit, Muay Thai, etc -, e suas promessas de garantia da saúde e da vida. O controle é duplo, tanto do cidadão, subjetivado a cuidar do seu corpo, quanto do Estado que faz atuar uma biopolítica do corpo saudável na cidade.

Como indicado anteriormente, um rápido passeio pela cidade nos coloca em contato com uma profusão de ofertas e produtos de naturezas distintas, mas com um traço comum, qual seja, a busca pelo bem estar. Esse discurso aparecerá em campanhas e/ou peças publicitárias da área da saúde, no campo das atividades físicas ou da alimentação, dentre outros. Desperta nossa atenção, o número considerável de ofertas de produtos enaltecendo garantias de felicidade e segurança, talvez uma demanda de nossa atualidade, delimitados por um discurso comum: o bem estar.

A imagem a seguir (figura 9), estampada em um outdoor da cidade de Uberlândia/MG, associa a conquista da felicidade, um dos imperativos do nosso tempo, ao corpo magro, a um 'cuidado de si' ligado a práticas individualistas de consumo e visibilidade social. Para atingir a 'felicidade prometida' (utópica), a imagem joga com uma construção discursiva genérica ('emagrecer') que funciona como algo capaz de atingir a todos aqueles que necessitam dessa demanda. $\mathrm{O}$ efeito será atingido se essa comunidade de leitores (clientes), ao trafegar pelas cidades e se deparar com a propaganda, sentirem-se convidados a controlar o peso do seu corpo em busca de uma vida feliz, de um corpo feliz e, obviamente, pagar o preço pelo tratamento. Tanto o aspecto generalizante do verbo 'emagrecer' quanto o imperativo do termo 'priorize' estabelece esse convite/chamada ao público. Convite disfarçado de palavra de ordem!

Conforme explicitamos, há uma conexão entre os discursos que circulam na cidade com uma dada produção de subjetividade, designada por Vigarello (2014) pela expressão 'sentimento de si'. Trata-se de estratégias que indicam a possiblidade de agirmos sobre o nosso humor (felicidade, bem estar) e nosso estado de alma através de um trabalho sobre o corpo (contratar o trabalho de uma clínica de emagrecimento, ou usar uma dieta x ou y). Indica um percurso que segue a trilha 'ser', 'saber' e 'ação'. Os enunciados do outdoor, do ponto de vista linguístico e imagético, organizam esses sentidos por meio de um jogo discursivo que propõe modos de vida, vinculada à ideia de saúde e de bem estar, encarnado em um dispositivo que estabelece processos de subjetivação. Há a construção de um modelo de corpo (padrão de beleza) indicado pela imagem de uma jovem mulher (magra e feliz) em situação de liberdade, segurando balões e tendo um espaço aberto ('céu azul') como pano de fundo. Essa imagem do corpo feminino encontra-se cercada pela sequência enunciativa "Emagrecer gera felicidade. Priorize", do lado esquerdo, e pelas indicações de valor e contato da clínica, 
pelo lado direito. Cruza a cena, uma trilha pontilhada vinculando a obtenção da felicidade ao corpo da jovem e ao local onde se pode obter a referida conquista. Aos interessados nessa conquista, basta seguir os pontos indicados e chegar ao resultado esperado, prometido. A linha pontilhada e os balões parecem indicar uma brincadeira infantil de ligar um ponto a outro, uma caça ao tesouro, pois joga com o morador da cidade e lhe indica as facilidades do tratamento: basta render-se ao tratamento, controlar o seu peso e pagar o preço.



O discurso da propaganda fixa a ideia de felicidade/bem estar ao corpo, por meio de enunciados que o transformam em uma superfície de inscrição de discursos, sobre o qual irão se instalar a disciplina e o controle, através de dietas, treinamentos etc.. Os valores do tratamento, indicados no outdoor, denunciam um fator excludente aos sujeitos ávidos por emagrecimento/felicidade, pois não são todos os moradores da cidade que terão condições socioeconômicas para ingressar em uma clínica de Spa. Como discute Birman (2010, p. 27), a felicidade, "custe o que custar", gestada na contemporaneidade, é geralmente destinada às classes médias e às elites, não são às classes populares, pois "essas não se inscrevem no projeto de felicidade que se tece na atualidade".

Um contraponto à propaganda do Spa, discutida anteriormente, pode ser observada no outdoor (figura 10) criado para a linha de suplementos alimentares, intitulado 'La Manne. Blessed nutricion', de autoria do artista Lamounier Lucas de Belo Horizonte. A exposição foi instalada em painéis publicitários de bancas de revistas da cidade de Belo Horizonte, no ano de 2007. A imagem integra o projeto 'Blessed' (abençoado), nome fictício que funciona como 'marca' dos produtos que integram a intervenção do artista no espaço da cidade. Essa 'marca' é acionada para designar três tipos de suplementos alimentares (aminoácidos, hipercalórico e whey ${ }^{7}$ ) de uso muito corrente entre atletas de academia e praticantes de esportes que desejam ganho de força

\footnotetext{
${ }^{7}$ Os três tipos de suplementação, indicados como produtos "abençoados" (blessed nutrition), são muito utilizados em academia e atividades esportiva, como forma de alimentação que auxilia na performance, reparação e ganho de massa muscular. Para maiores informações, consultar Pereira Júnior (2007) e o site http://www.corpoperfeito.net.br/.
} 
e massa muscular. Em sua composição imagética e textual, o artista joga, ironicamente, com o discurso do consumo (divulga produtos), com o discurso religioso (citação do texto bíblico) e com ideia de corpo perfeito, tema tão recorrente na atualidade. Trata-se de um trabalho artístico, que aciona os recursos composicionais da publicidade, para intervir no espaço urbano, desenvolvendo um trabalho crítico sobre uma dada concepção de corpo (alimentação, beleza e força) atravessada pelo discurso religioso e do consumo.

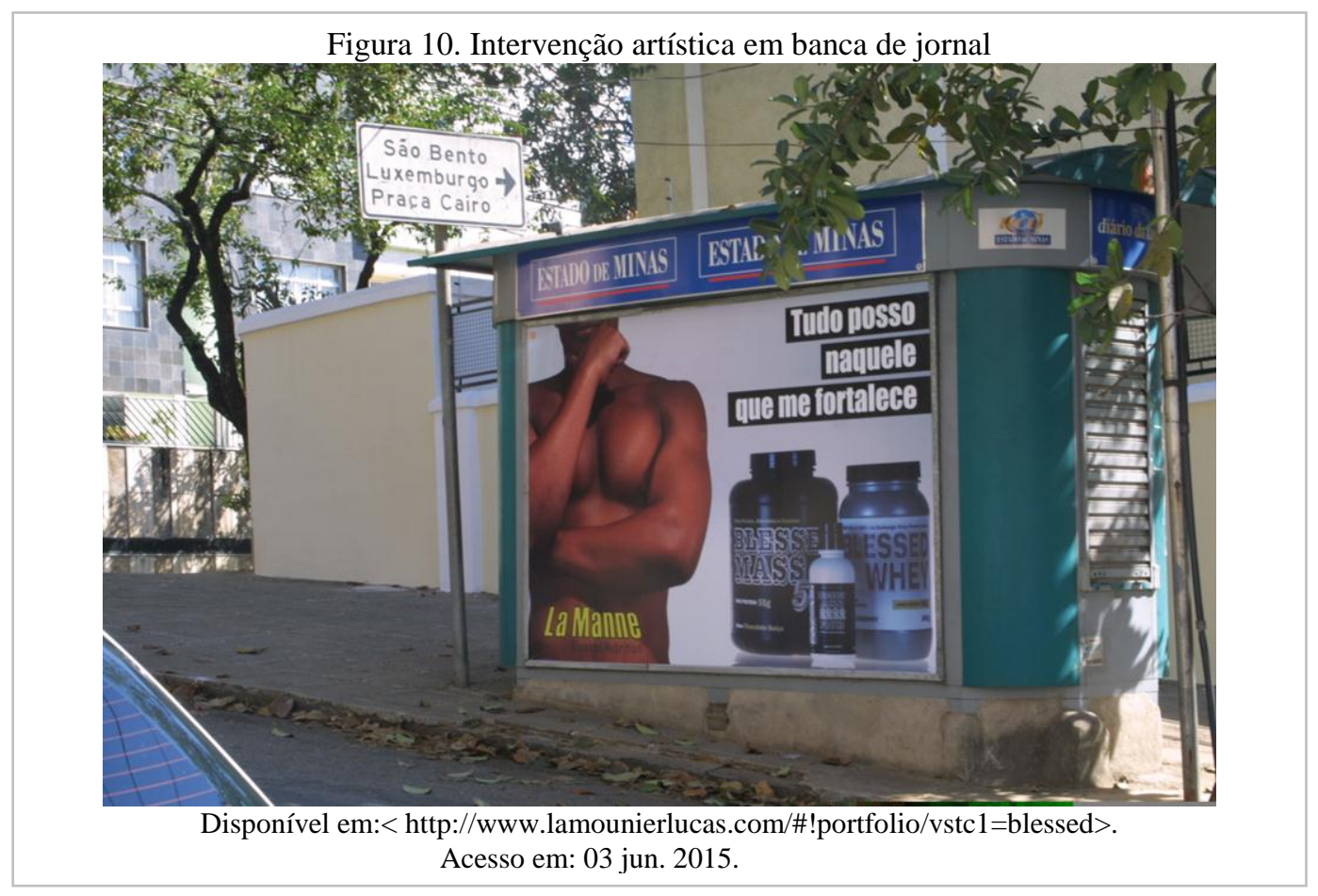

Estamos diante de uma propaganda que não é propaganda, pois não está exposta para comercialização de um produto, embora os suplementos alimentares sejam reconhecíveis, tanto pelo formato dos objetos (embalagens) quanto pelos nomes (amino, mass, whey). Há uma estratégia discursiva nessa intervenção que se materializa em enunciados que objetivam um modelo de fortaleza, deslocado do discurso religioso ('naquele' - Deus) para o campo da nutrição esportiva, na qual o termo 'fortalece' filiase ao uso de suplementos ('naquele') e liga-se ao sujeito ('me'). Nesse jogo de invenção de produtos e conceitos, realizada pelo aproveitamento do discurso religioso e discurso das dietas esportivas, a peça artística ironiza com a busca por um modelo de bem estar corrente na atualidade: o corpo perfeito. Se no campo religioso a fortaleza está em Deus/Igreja, no espaço das dietas e dos suplementos contemporâneos, essa fortaleza está no corpo, em um corpo forte, musculoso.

Nessa imagem, o artista destila sua crítica ao consumo de produtos que prometem respostas imediatas e ao discurso religioso, pois, em ambos os casos, o sujeito é convidado a estabelecer outras relações com o que Foucault designa com o 'cuidado de si'. No campo religioso, essa relação é delegada a um Deus (pastor das almas); no cenário contemporâneo, a 'fortaleza' está no uso de técnicas que visam a obtenção de um corpo perfeito (nova religião?). O trabalho de Lamounier nos convida a repensar as práticas discursivas contemporâneas ligadas ao bem estar e a estetização do corpo. Evidencia, também, como o espaço urbano abriga possibilidades de resistências.

No outdoor anterior, a felicidade pode ser encontrada através de um programa de emagrecimento, designada pela linha pontilhada que liga a imagem à Clínica de Spa. No 
outdoor dos suplementos esportivos, o bem estar e a força física, aparecem indicados pelo enunciado 'naquele', pronome demonstrativo, que cumpre a função de conectar a imagem de um corpo 'perfeito' e produto. Ao sujeito que circula pela cidade, fica o convite para estabelecer identificações, relações e subjetivações com os discursos que o espaço urbano nos oferece.

\section{Algumas conclusões}

As imagens exploradas neste estudo nos mostram como o espaço urbano é marcado por multiplicidades, exclusões e por um apelo constante aos sujeitos para um sentimento/cuidado de si e do corpo. De certo modo, o discurso ligado ao bem estar e a temas correlatos, tais como felicidade, liberdade, saúde e segurança, por exemplo, materializa-se em dispositivos de poder finos e sutis que, constantemente, nos convidam a um cuidado com o corpo, inserindo a vida da população em uma estratégia biopolítica. A temática do bem estar, desenvolvida por Foucault e focalizada nos textos aqui estudados, aponta para certa construção de um sentimento de si na atualidade, atravessado por um movimento narcísico (beleza, felicidade, saúde, etc.), que reitera a fabricação de uma produção de subjetividade capitalística, delimitada pelo consumo e aquisição de uma vida saudável a qualquer custo. Por outro lado, há imagens que promovem resistência ao padrão de vida imposto, compondo linhas de fuga e espaços para questionamentos. De um modo ou de outro, somos tocados/invadidos nos mais diversos e mínimos lugares o tempo todo por uma profusão de textos e imagens que as cidades nos oferecem.

Os dispositivos de segurança, criados no momento de formação das grandes cidades e com o advento do capitalismo, tinham como função assegurar o bem estar no meio urbano, cuidando da distribuição espacial do espaço citadino, da higiene, do controle das doenças etc. Esses dispositivos estabeleciam as formas de estar/viver no espaço urbano. $\mathrm{O}$ que se percebe com as mudanças históricas que transcorreram do século XVIII aos dias atuais, é que esses dispositivos passaram por transformações e são atravessados por outros discursos que tanto afetam a sensibilidade corporal dos cidadãos quanto o corpo da população.

Os discursos inscritos nos textos analisados, cuja circulação poderia figurar em outras cidades brasileiras, para ficar nesse exemplo, indicam uma demanda de nossa atualidade, uma urgência de nosso tempo histórico, no qual a promessa de bem estar e segurança, bem como os produtos que se vinculam a esse eixo temático, encarnam-se em gestos, produtos e propagandas que incidem sobre o corpo, no corpo. No material analisado, corpo e subjetividade estão constantemente convocados a checar, experimentar e se deslocar de sua condição (gordo, não saudável, infeliz, por exemplo) em busca de novas identidades e novas técnicas para maximizar os resultados com o corpo e com a saúde. A busca por uma saúde perfeita/corpo perfeito chega a um ponto em que o alimento passa a ser oferecido na condição de remédio. Essa constatação nos faz retomar a pergunta, já indicada neste texto, e formulada a partir do pensamento de Foucault: de qual corpo nossa sociedade precisa?

Essas reflexões fazem coro ao texto "Considerações acerca do cuidado de si mesmo contemporâneo", de Prado Filho (2009), quando busca responder o que seria o cuidado de si na atualidade. Para tanto, o autor faz um recuo à antiguidade clássica para entender o funcionamento da ética grega e do cuidado de si mesmo para, em seguida, verificar se temos, no contexto contemporâneo, o mesmo funcionamento, ou seja, o que é o cuidado do si mesmo hoje? A resposta é negativa, primeiro por não se tratar do mesmo sujeito, o antigo e contemporâneo (universal, transistórico, naturalizado), nem 
da mesma historicidade. Toda a problemática do 'ocupa-te de ti mesmo', vinculado à ética grega, desloca-se para outro espaço ligado a um 'cuidado de si mesmo' voltado para a estetização do corpo ('corpolatria'), produzido nas academias, clínicas, etc. e estetização da subjetividade, que migra dos espaços privados da intimidade/privacidade para outros espaços da cidade. Para esse autor, o conhecimento de si banaliza-se na atualidade e desloca-se para a uma construção/sentimento de si voltada para a exaltação do belo, da boa saúde, do corpo perfeito, do imperativo da felicidade, do sucesso, dentre outros.

Ainda assim, reiteramos que a cidade apresenta, também, possibilidades de resistências, nas quais os sujeitos são convidados a refletir sobre os discursos que circulam no espaço urbano e a se posicionar frente aos dispositivos de poder que atuam na produção de subjetividade na atualidade.

\section{Referências}

ASSMANN, S. J.; STASSUN, C. C. Dispositivo: Fusão de objeto e método de pesquisa em Michel Foucault. In: Caderno de Pesquisa Interdisciplinar em Ciências Humanas. Florianópolis, v.11, n.99, p. 72-92, jul/dez. 2010. Disponível em: https://periodicos.ufsc.br/index.php/cadernosdepesquisa/article/view/14744

BIRMAN, Joel. Muitas felicidades?! O imperativo de ser feliz na contemporaneidade. In: FREIRE FILHO, J. (Org.). Ser feliz hoje. Reflexões sobre o imperativo da felicidade. Rio de Janeiro: FGV, 2010.

FOUCAULT, M. Segurança, território, população. São Paulo: Martins Fontes, 2008.

Vigiar e punir: nascimento da prisão. Petrópolis: Vozes, 1987.

As malhas do poder. In:

Segurança, penalidade, prisão. Rio de Janeiro: Forense Universitária, 2012. (Ditos e escritos 8)

Espaço, saber e poder. In: Segurança, penalidade, prisão. Rio de

Janeiro: Forense Universitária, 2012b. (Ditos e escritos 8)

Poder e corpo. In:

Filosofia, diagnóstico do presente e verdade. Rio

de Janeiro: Forense Universitária, 2014. (Ditos e escritos 10)

A extensão social da norma. In:

Arte, epistemologia, filosofia e

história da medicina. Rio de Janeiro: Forense Universitária, 2011. (Ditos e escritos 7)

O nascimento da medicina social. In: Microfísica do poder. Rio de Janeiro: Edições Graal, 2003.

História da sexualidade I: a vontade de saber. Rio de Janeiro: Edições Graal, 1988.

MARTINS, J. C. A vida dos corpos e das populações como objeto de uma biopolítica na obra de Michel Foucault. In: O legado de Foucault. São Paulo: Editora da UNESP, 2006.

PEREIRA JÚNIOR, Lamounier Lucas. No exterior do cubo branco. Os veículos publicitários de mídia exterior como suporte para as intervenções artísticas no espaço urbano. Dissertação (Mestrado) - Universidade Federal de Minas Gerais, Escola de Belas Artes, 2007.

PRADO FILHO, Kleber. Considerações acerca do cuidado de si mesmo. In: TEDESCO, Silvia; NASCIMENTO, Maria Lívia. Ética e subjetividade: novos impasses. Porto Alegre: Sulina, 2009. p 231-245

VIGARELlO, G. Le Sentiment de soi. Histoire de la perception du corps. Paris: Éditions du Seuil, 2014. 